\section{Pre and post test HAMA scores in women undergoing oral glucose challenge test}

\section{Pre i post test HAMA skor u trudnica podvrgnutih O'Sullivan testu}

Dragan Savkovic ${ }^{1}$, Tatjana Perovic ${ }^{2}$, Eliana Garalejic ${ }^{3}$, Biljana Arsic ${ }^{3}$, Milan Perovic ${ }^{3}$, MiroslavaGojnic Dugalic ${ }^{4}$, Uros Babic ${ }^{5}$

${ }^{1}$ Hospital "Sveti Vracevi", Bjeljina, Bosnia and Herzegovina ${ }^{2}$ Clinical Hospital Center "Zvezdara", Belgrade, Serbia

${ }^{3}$ Clinic for Gynecology and Obstetrics "Narodni front", Belgrade, Serbia

${ }^{4}$ Clinic for Gynecology and Obstetrics, Clinical center of Serbia, Belgrade, Serbia

${ }^{5}$ Clinic of urology, Clinical Center "Dr Dragiša Mišović-Dedinje"Belgrade, Serbia

\section{Abstract}

The 50-gram non-fasting one hour Glucose Challenge Test (GCT) is today the one most widely implemented as a screening test for Gestational Diabetes Mellitus (GDM). Positive result of GCT creates a preliminary GDM diagnosis. Diagnosis of GDM labels a pregnancy high risk. Any highrisk pregnancy can cause maternal anxiety. The aim of the study was to investigate pretest and posttest anxiety levels in pregnant women undergoing GCT. Anxiety levels were evaluated by Hamilton Rating Scale for Anxiety (HAMA score). Pretest HAMA score was $7.1 \pm 3.34$ in the women with preliminary GDM diagnosis, and $6.69 \pm 5.51$ in the women with negative GCT results. After delivering GCT results, HAMA score was $8.64 \pm 8.10$ in the women with preliminary GDM diagnosis and 4.29 \pm 2.29 in the women without preliminary GDM diagnosis. Pretest levels of anxiety among all pregnant women undergoing GCT were increased. However, this was temporary in women with negative GCT, whose anxiety levels decreased after delivering GCT results. Among women preliminary diagnosed with GDM, posttest HAMA evaluation revealed sustained increased levels of anxiety. Concerns regarding the anxiety caused by screening for GDM were confirmed by the results of our study.

Keywords: glucose challenge test, HAMA
Dragan Savković ${ }^{1}$, Tatjana Perović2 , Eliana Garalejić ${ }^{3}$,

BiljanaArsić ${ }^{3}$, Milan Perović ${ }^{3}$, Miroslava Gojnić Dugalić ${ }^{4}$, Uroš Babić ${ }^{5}$

${ }^{1}$ Bolnica „Sveti Vračevi“, Bijeljina, Bosna i Hercegovina

${ }^{2}$ Kliničko-bolnički centar „Zvezdara“, Beograd, Srbija

${ }^{3}$ Klinika za ginekologiju i akušerstvo „Narodni front“", Beograd, Srbija

${ }^{4}$ Klinika za ginekologiju i akušerstvo, Klinički centar Srbije, Beograd, Srbija

${ }^{5}$ Klinika za urologiju, Klinički centar „Dr Dragiša Mišović- Dedinje”Beograd, Srbija

\section{Apstrakt}

Test oralnog opterećenja sa 50 g glukoze (GCT) je najprihvaćeniji skrining test za gestacioni dijabetes melitus (GDM). Pozitivan rezultat GCT-a označava preliminarnu dijagnozu GDM-a. Postavljanje dijagnoze GDM-a takvu trudnoću svrstava u red visoko-rizičnih trudnoća, što može uzrokovati anksioznost trudnice. Cilj studije je da ispita nivo anksioznosti uz pomoć Hamilton Rating Scale for Anxiety (HAMA score), a pre i nakon izvođenja GCT-a. Pretest HAMA score je bio 7.1 $\pm 3.34 \mathrm{u}$ žena sa preliminarnom GDM dijagnozom i $6.69 \pm 5.51 \mathrm{u}$ žena sa negativnim GCT rezultatom. Nakon saopštavanja GCT rezultata, HAMA score je iznosio $8.64 \pm 8.10 \mathrm{u}$ žena sa preliminarnom GDM dijagnozom i $4.29 \pm 2.29$ u žena bez te dijagnoze. Pretest nivoi anksioznosti kod svih žena koje su podvrgnute GCT-u su bili povišeni. Ova anksioznost je bila privremena kod žena sa negativnim GCTom, jer se ona smanjivala nakon saopštavanja GCT rezultata. Kod žena sa preliminarnom dijagnozom GDM-a, posttest HAMA score vrednosti su ostale visoke i nakon saopštavanja rezultata GCT-a. Pretpostavke o skriningu GDM-a, kao jednom od uzroka anksioznosti potvrđene su rezultatima ove studije.

Ključne reči: oralni test opterećenja glukozom, HAMA skor

\title{
Introduction
}

Gestational diabetes mellitus (GDM) is defined as diabetes first diagnosed in pregnancy and has an important impact on perinatal morbidity and mortality. The 50-gram non-fasting one hour glucose challenge test (GCT), is today the one most widely implemented as a screening test for GDM ${ }^{1}$. Positive result of GCT creates a preliminary GDM diagnosis. Definitive GDM diagnosis is established after positive oral 75 or 100-g fasting glucose tolerance test (oGTT), which is considered as gold standard for GDM diagnosis ${ }^{2}$. 
Diagnosis of GDM labels a pregnancy high risk. Any high-risk pregnancy can cause maternal anxiety. Anxiety is the conscious and reportable experience of intense dread and foreboding, conceptualized as internally derived and unrelated to external threat. A high-risk pregnancy is defined as any gestation in which the prospects of an optimal outcome for the mother or the child are decreased. Synder suggests that a high-risk pregnancy is complex because the woman must cope with two distinct crisis situations. Firstly, the normal developmental crisis of childbearing as well as the recognition that the pregnancy may not progress along normal patterns or and with a healthy mother-infant dyad3. As a result of this condition, the mother $\mathrm{s}$ abilities to cope are extremely taxed and anxiety often results. Very little research has been done to discover the psychological impact of GDM screening and preliminary GDM diagnosis. Furthermore, the prevalence and clinical presentation of anxiety disorders during pregnancy and the postpartum period have received little research attention ${ }^{3}$.

The aim of the study was to investigate pretest and posttest anxiety levels in pregnant women undergoing GCT.

\section{Material and methods}

The standard practice in Clinic for Gynecology and Obstetrics, Clinical Center of Serbia is to perform a routine GCT between the 24th and 28th week of pregnancy in patients with high risk for GDM. Women failing that test (blood sugar level greater than $140 \mathrm{mg} / \mathrm{dl}$ ) are given a preliminary GDM diagnosis. Test results are delivered by physician. At that point the woman is scheduled to come in to the clinic for definitive diagnostic test, oGTT.

Sample selection began with the first client appearing for the GCT during the study period. Patients were approached by the investigators, TZ and DS as they waited in the laboratory waiting room. Those who had been diagnosed with GDM in a previous pregnancy were excluded. Others were invited to participate and given the informed consent materials. When the informed consent form was signed by patient and investigators, the patient was given the pre-test instrument. The pre-test questionnaire was used to measure the participant's initial anxiety regarding GCT which was about to come. To measure anxiety, the Hamilton Rating Scale for Anxiety (HAMA) scale was performed. This included 14 items, designed to evaluate mental and somatic symptoms with a score of $0-4$ for each item and a total score ranging from 0 to 564 . The pre-test questionnaire was used to measure the patient's initial anxiety. After pre-test HAMA scoring, participant underwent GCT. GCT results were delivered by physician and after that went through post-test HAMA scoring. The post-test consisted of identical questions in different order. The post-test was used to measure anxiety after delivery of GCT results and preliminary GDM diagnosis in patients with positive GCT. Data were collected through a written pre- and post-test questionnaire (HAMA scale). Sample selection began on 1st October, 2011 and concluded in 31st of January 2012. A total of 45 individuals participated in this study.

Data is expressed as mean values with standard deviation. The t-test was used to determine the significance of changes between pre- and post-test anxiety between participants preliminary diagnosed with GDM and those who screened negatively. A P value of $<0.05$ was considered statistically significant.

\section{Results}

The prevalence of preliminary GDM diagnosis in our study population was $22.22 \%$. Characteristics of the study participants are presented in table 1 . There were no significant differences between those participants with preliminary GDM diagnosis and those with negative GCT.

\begin{tabular}{|l|l|l|l|}
\hline \multirow{2}{*}{ Variable } & Preliminary GDM & Negative GCT & \multirow{2}{*}{$\mathrm{p}$} \\
\cline { 2 - 4 } & $\mathrm{N}(\%)$ & $\mathrm{N}(\%)$ & 0.624 \\
\hline Age (Year)* & $27.14 \pm 4.12$ & $26.07 \pm 5.89$ & 0.435 \\
\hline Nulliparity & $4(40)$ & $15(42.8)$ & 0.021 \\
\hline Secundigravida & $2(20)$ & $6(17.2)$ & 0.055 \\
\hline Tercigravida & $3(30)$ & $9(25.7)$ & \\
\hline
\end{tabular}




\begin{tabular}{|l|l|l|l|}
\hline Multiparity & $1(10)$ & $5(14.3)$ & 0.061 \\
\hline Primary school level & $2(20)$ & $8(22.8)$ & 0.021 \\
\hline High school level & $6(60)$ & $20(57.4)$ & 0.256 \\
\hline University level & $2(20)$ & $9(25.8)$ & 0.053 \\
\hline Family history of diabetes & $5(50)$ & $17(48.6)$ & 0.071 \\
\hline Obesity & $2(20)$ & $8(22.8)$ & 0.021 \\
\hline Marital status & $8(80)$ & $29(82.8)$ & 0.06 \\
\hline
\end{tabular}

*; age is presented as $\mathrm{X} \pm \mathrm{SD}$.

Table 1. Characteristics of study participants

Pregnant women with preliminary diagnosis of GDM were found to differ in their post test HAMA scores from a group of pregnant women with negative GCT results. Pretest HAMA score was $7.1 \pm 3.34$ in the women who were given preliminary GDM diagnosis after GDM, and 6.69 \pm 5.51 in the women with negative GCT results, but the differences were not statistically significant ( $\mathrm{p}>0.05)$. Statistically significant difference $(p<0.05)$ was found in post test HAMA scores between women with positive GCT results and women with negative GCT results. After notifying GCT results to participants, posttest evaluation of anxiety by HAMA score was $8.64 \pm 8.10$ in the women with preliminary GDM diagnosis and 4.29 \pm 2.29 in the women without preliminary GDM diagnosis.

\section{Discussion}

Taking into consideration the high prevalence of anxiety disorders in women, it follows that considerable numbers of women will reveal symptoms and may as a result benefit from preventing any kind of anxious events during pregnancy. There is consequently a need to conduct the studies of those events in pregnancy that could negatively influence perinatal mental health or perinatal anxiety disorders ${ }^{5}$. Overaction of the maternal neuroendocrine system has been implicated in negative health effects seen in fetuses born to strained or anxious mothers. Fetal exposure to elevated levels of hormones (predominantly cortisol) may contribute to premature labor 6,7 . Maternal exposure to stress and anxiety may precipitate the release of catecholamines that can consequence in maternal vasoconstriction and finally a limitation of oxygen and essential nutrients to the fetus ${ }^{8}$. Consequently, we should avoid any unnecessary action during the management and/or monitoring of pregnancies 9 . Because of the hazards associated with GDM for both mother and child, screening and diagnosis of the condition can be distressing. In order to eliminate distress issues of screening tests we could think about less aggressive screening tests, in example those that do not require blood sampling. Our study results confirmed such thoughts. Pretest levels of initial anxiety among all pregnant women undergoing GCT were increased. Comparison of pre- and post- test anxiety indicates significant changes after reading of GCT results. Posttest HAMA evaluation revealed sustained increased levels of anxiety only in participants with preliminary GDM diagnosis.

In accordance with our results and thoughts different authors agreed on increased anxiety related to screening tests in pregnancy and found that the perception of health was lower in women who had a false-positive result of glucose challenge test than in women who were not tested or whose test results were negative ${ }^{10,11,12}$. In contrast, others found no difference in anxiety scores for women with GDM compared with healthy control subjects some weeks after diagnosis. However, they opined that if there had been a negative effect at the time of diagnosis, then this was not operative some weeks later ${ }^{13}$. Still, women were positive about the advantages of testing during pregnancy and indicated their willingness to be tested during any subsequent pregnancy ${ }^{14}$. 


\section{Conclusion}

Pretest levels of anxiety among all pregnant women undergoing GCT were increased. However, this was temporary in women with negative GCT, whose anxiety levels decreased after delivering GCT results. Among women preliminary diagnosed with GDM, posttest HAMA evaluation revealed sustained increased levels of anxiety. Concerns regarding the anxiety caused by screening for GDM were confirmed by the results of our study.

\section{Literature}

1. Perović M, Garalejić E, Gojnić M, Arsić B, Pantić I, Jović Bojović D, Fazlagić A, Gardiner H. Sensitivity and specificity of ultrasonography as a screening tool for gestational Diabetes Mellitus. The Journal of Maternal-Fetal \& Neonatal Medicine 2012; 25 (8):1348-1353.

2. American Diabetes Association. Gestational diabetes mellitus. Diabetes Care 2003; 26 (Suppl 1): 103-105.

3. Ross LE, McLean LM. Anxiety Disorders During Pregnancy and the Postpartum Period: A Systematic Review. J Clin Psychiatry 2006; 67:127-130.

4. Hamilton M. The assessment of anxiety states by rating. The British Journal of Medical Psychology 1959; 32:50-55.

5. Matthey S. Detection and treatment of postnatal depression (perinatal depression or anxiety). Curr Opin Psychiatry 2004; 17:21-29.

6. Sandman CA, Wadhwa PD, Dunkel-Schetter C, et al. Psychobiological influences of stress and HPA regulation on the human fetus and infant birth outcomes. Ann N Y Acad Sci 1994;739:198-210.

7. Wadhwa PD, Sandman CA, Porto M, et al. The association between prenatal stress and infant birth weight and gestational age at birth: a prospective investigation. Am J Obstet Gynecol 1993;169:858-865.

8. Copper RL, Goldenberg RL, Das A, et al. The preterm prediction study: maternal stress is associated with spontaneous preterm birth at less than thirty-five weeks' gestation. National Institute of Child Health and Human Development Maternal-Fetal Medicine Units Network. Am J Obstet Gynecol 1996;175:1286-1292.

9. Mancuso A, De Vivo A, Fanara G, Settineri S, Giacobbe A, Pizzo A. Emotional state and dreams in pregnant women. Psychiatry Research 2008; 160: 380-386.

10. Kerbel D, Glazier R, Holzapfel S, Yeung M, Lofsky S: Adverse effects of screening for gestational diabetes: a prospective cohort study in Toronto, Canada. J Med Screening 1997;4:128-132.

11. Geller PA. Pregnancy as a Stressful Life Event. CNS Spectrums 2004;9:188-197.

12. Daniells S, Grenyer B, Davis WS, Coleman CJ, Burges JA, Moses R. Gestational Diabetes Mellitus: Is a diagnosis associated with an increase in maternal anxiety and stress in the short and intermediate term? Diabetes Care 2003;26:385-389.

13. Spirito A, Williams C, Ruggerio L, Bond A, McGarvey ST, Coustan D: Psychological impact of the diagnosis of gestational diabetes. Obstet Gynecol 1989; 73:562-566.

14. Griffiths R, Rodgers D, Moses R: Patients' attitudes towards screening for gestational diabetes mellitus in the Illawarra Area, Australia. Diabetes Care 1993; 16:506-508.

Corresponding author:

dr Dragan Savkovic

Address: Gavrila Principa 5, 76300 Bijeljina,

Bosnia and Herzegovina

E-mail: drsavkovic@gmail.com 